\title{
13. STRATIGRAPHY AND DIAGENESIS OF THE CARBONATE PLATFORM AT SITE 873, WODEJEBATO GUYOT ${ }^{1}$
}

\author{
Jonathan M. Lincoln, ${ }^{2}$ Paul Enos, ${ }^{3}$ and Jim G. $\mathrm{Ogg}^{4}$
}

\begin{abstract}
Based on the study of 175 shipboard and shore-based thin sections from the carbonate platform section of Site 873 on Wodejebato Guyot, we conclude that a general shift occurs from packstone and grainstone textures at the base of the platform (Core 144-873A-11R) to dominantly packstone and wackestone textures in Cores 144-873A-7R, -6R, and -5R. There is a decided shift back to grainier depositional textures beginning in Core 144-873A-4R and continuing to the top of the platform section. These textural trends are accompanied by related changes in cement, porosity, and fossil type and abundance. The grainstones were laid down during the initial transgression of the volcanic edifice, followed by a general deepening of the lagoon that resulted in the uphole increase in mud at Site 873. Rhizoliths, fenestra with vadose cements, and negative carbon isotope composition of the fine-grained sediment in parts of Core 144-873A-5R may indicate subaerial exposure. A second transgression event deposited grainstones and algal bindstone facies on top of the exposure surface (Cores 144-873A-4R, $-3 \mathrm{R}$, and -2R, and Cores 144-873B$10 \mathrm{~N},-9 \mathrm{~N}$, and $-8 \mathrm{~N}$ ). The carbon and oxygen isotope composition of fossil components and cements in these cores suggests occasional supratidal deposition and exposure to meteoric waters. Carbonate production on Wodejebato ceased before waters again deepened at Site 873.

Interpretation of facies based on physical and geochemical logs indicates that numerous grainy storm beds interrupt the deposition of more lagoonal wackestones and packstones throughout the carbonate platform section of Site 873. The boundary between the well-cemented packstones and wackestones of Core 144-873A-5R and the overlying grainstones occurs at about 90 mbsf.
\end{abstract}

\section{INTRODUCTION}

Wodejebato Guyot is located northwest of Pikinni Atoll in the Ralik Chain of the northern Marshall Islands (see site map preceding title page). The Ralik Chain is the second of three northwest-trending, en echelon chains of seamounts, guyots, and atolls that comprise the Marshall Islands. Five holes were drilled on Wodejebato Guyot as part of Leg 144 (Premoli Silva, Haggerty, Rack, et al., 1993): Site 873 is located within the center of the broad guyot, Sites 874 and 877 are located approximately $20 \mathrm{~km}$ north of Site 873 on the inner of two perimeter ridges that bound the northeast side of the guyot, and Sites 875 and 876 are located on an outer perimeter ridge, only a few kilometers east of Sites 874 and 877 , respectively (Fig. 1).

The specific objectives of drilling Wodejebato Guyot were (1) to relate the acoustic stratigraphy of pelagic sediments that cap the atoll to their depositional and diagenetic history; (2) to date the cessation of platform growth and the onset of pelagic sedimentation; (3) to determine the change in shallow-water facies with time in lagoonal and reef settings; (4) to examine the diagenesis of the platform limestones; (5) to establish the history of platform drowning, emergence and subsidence; (6) to establish the age and paleolatitude of the underlying volcanic edifice; (7) to study the geochemical characteristics of the volcanic rocks; and (8) to compare the stratigraphy of Wodejebato with the living, adjacent Pikinni Atoll. Wodejebato Guyot and Pikinni Atoll share the same volcanic pedestal and are connected by a volcanic ridge at a water depth of approximately $1500 \mathrm{~m}$. This paper uses shipboard and shore-based data from Site 873 to partly address objectives 3, 4, and 5: we use petrographic and logging data to determine the change in shallow-water facies with time in the former Wodejebato lagoon; we

\footnotetext{
${ }^{1}$ Haggerty, J.A., Premoli Silva, I., Rack, F., and McNutt, M.K. (Eds.), 1995. Proc. ODP, Sci. Results, 144: College Station, TX (Ocean Drilling Program).

${ }_{2}^{2}$ Department of Earth and Environmental Studies, Montclair State University, Upper Montclair, NJ 07043, U.S.A.

${ }^{3}$ Department of Geology, The University of Kansas, 120 Lindley Hall, Lawrence, KS 66045, U.S.A.

${ }^{4}$ Department of Earth and Atmospheric Sciences, Purdue University, West Lafayette, IN 47907 , U.S.A
}

use petrographic and isotopic methods to examine the diagenesis of platform carbonates recovered at Site 873; and we use these data to fill in parts of the guyot's emergence and subsidence history.

\section{PREVIOUS WORK}

The Pikinni and Anewetak atolls were drilled in 1947 and 1952, respectively, as part of Operation Crossroads (Emery et al., 1954). The deeper of the two holes drilled at Pikinni Atoll penetrated $780 \mathrm{~m}$ of coral-algal, reef-related sediments and reached strata of early Miocene and Oligocene(?) age; volcanic basement was not reached in either hole (Cole, 1954; Emery et al., 1954). A stratigraphic section equivalent to that drilled at Pikinni was penetrated at the top of two holes drilled on Anewetak Atoll in 1952 (Cole, 1957; Schlanger, 1963). Basalt, directly overlain by reef, fore-reef, and outer-slope sediments of late Eocene age, was reached at depths of 1271 and 1388 $\mathrm{m}$ below Anewetak Atoll. This basalt has recently been dated at 75.9 $\pm 0.6 \mathrm{Ma} \mathrm{by}{ }^{40} \mathrm{Ar} /{ }^{39} \mathrm{Ar}$ methods (Lincoln et al., 1993). Seismic refraction studies at Pikinni Atoll revealed a high surface relief layer with a velocity of about $4 \mathrm{~km} / \mathrm{s}$, thought to be the top of the volcanic edifice, at a depth of about $1300 \mathrm{~m}$ (Raitt, 1954). A basement depth of 1500-1600 m was estimated for Pikinni Atoll from aeromagnetic surveys (Alldredge et al., 1954). Based on similar depths to volcanic basement, and similar subsidence histories inferred from biostratigraphic correlation (Cole, 1957), Pikinni Atoll was assumed to be contemporaneous with the edifice beneath Anewetak Atoll.

Wodejebato was dredged as part of the Scripps Institution of Oceanography Mid-Pacific Expedition of 1950. These dredging efforts recovered basalts and a tuff breccia, the cracks of which were filled with phosphatized, planktonic foraminifers of Eocene age (Hamilton and Rex, 1959). Emery et al. (1954) suggested that eruption in shallow water was indicated by the highly vesicular and scoriaceous nature of the dredged volcanic rocks; the high proportion of hyaloclastic material in the dredge hauls indicated submarine eruptions.

Rocks similar to those recovered during the Mid-Pacific Expedition were recovered from the south side of Wodejebato Guyot during a 1981 Hawaii Institute of Geophysics cruise (KK810626; Peterson et al., 1986). One piece of hyaloclastite contained shallow-water 


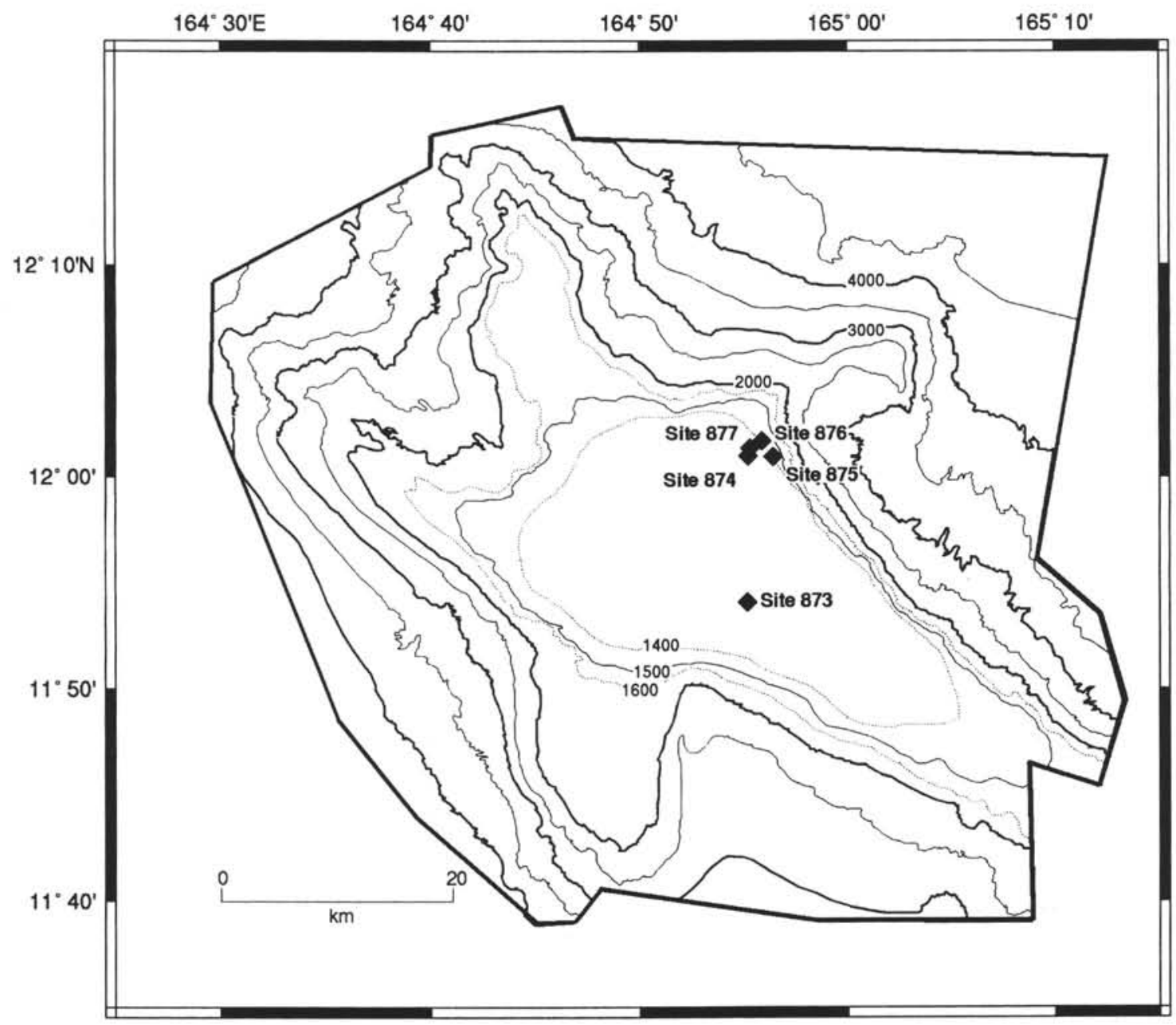

Figure 1. Bathymetric map of Wodejebato Guyot compiled from seismic and SeaMARC II surveys (Bergersen, 1993), showing the location of Site 873 in the center of the broad platform relative to Sites 874-877, which are drilled on the margin of the guyot.

peloids, fragments of a larger benthic foraminifer, calcareous red algae, and bryozoan fragments.

During a 1988 site survey by the Moana Wave (MW8805), manganese-coated vesicular basalt, hyaloclastite, basalt breccia, and moderately to well lithified pelagic sediments were recovered from the talus slopes that flank Wodejebato Guyot. Most of the planktonic foraminifers constrain the age of volcanism to be Eocene or older (Lincoln et al., 1993). One sample contains poorly preserved clasts within a matrix containing early Tertiary fossils. The clasts contain Late Cretaceous (possibly late Santonian to earliest Campanian) planktonic foraminifers. Rounded basalt pebbles in several conglomerates indicate subaerial erosion of the volcanic edifice. Dredging at the slope break on the south side of Wodejebato Guyot during this same site survey recovered manganese-encrusted, coarse-grained, poorly sorted, shallow-bank limestones containing larger foraminifers, calcareous algae, coral fragments, echinoid debris, bryozoan fragments, and molluscan debris (Lincoln et al., 1993). The larger foraminifer assemblage in these limestones is similar to a Campanian to Maastrichtian assemblage recovered in turbidites at Site 462 in the Nauru Basin, south of Wodejebato Guyot (Premoli Silva, 1986). Specimens of a primitive Orbitoides, possibly $O$. tissoti, were also present in the dredged limestones; the biostratigraphic range of these primitive orbitoids is from early to middle Campanian. Several poorly preserved shell fragments and whole specimens of radiolitid and caprinid rudists were recovered in the same dredge.

Based on integration of seismic surveys, SeaMARC II side-scan sonar images, and dredge results collected during the 1988 site survey and a later 1990 survey (MW9009), this guyot was interpreted to consist of a volcanic edifice with gullied slopes, a reef rim surrounding lagoonal sediments, and a conical cap of pelagic sediments (Bergersen, 1993). Sites 874-877 were drilled into ridges along the perimeter of this former atoll; Site 873 was drilled into the former lagoon.

\section{OVERVIEW OF SITE 873 LITHOSTRATIGRAPHY}

Site 873 is located at $11^{\circ} 54^{\prime} \mathrm{N}, 164^{\circ} 55^{\prime} \mathrm{E}$ in a water depth of 1334 $\mathrm{m}$. Two holes were drilled at Site 873; Hole 873B was located $100 \mathrm{~m}$ to the northeast of Hole $873 \mathrm{~A}$. Cores were recovered using a rotary core barrel from 54.3 to 232.3 mbsf after washing through the pelagic cap at Hole $873 \mathrm{~A}$. The drilling crew recovered $58 \mathrm{~m}$ of pelagic sediments from Hole 873B and then cored to a total depth of $69 \mathrm{mbsf}$ using a motor driven core barrel. Recovery within the carbonate platform was $2.4 \%$ in Hole $873 \mathrm{~A}$ and $39.1 \%$ in Hole $873 \mathrm{~B}$.

The shipboard lithostratigraphic summary is shown in Figure 2. Unit I is comprised of soupy nannofossil foraminifer ooze that grades into homogeneous foraminifer ooze downhole. Unit II consists of a layer of manganese-encrusted, limestone conglomerate with platform carbonate lithoclasts. The matrix is a skeletal packstone. Unit II contains abundant pelagic internal sediment in burrows and fractures. The pelagic sediments range in age from late Paleocene to middle Eocene. Unit III is comprised of $93.36 \mathrm{~m}$ of platform carbonates dominated by packstone and grainstone with significant intervals of wackestone. Components include abundant benthic foraminifers (mostly larger foraminifers and miliolids), common algae (especially 
Hole 873A

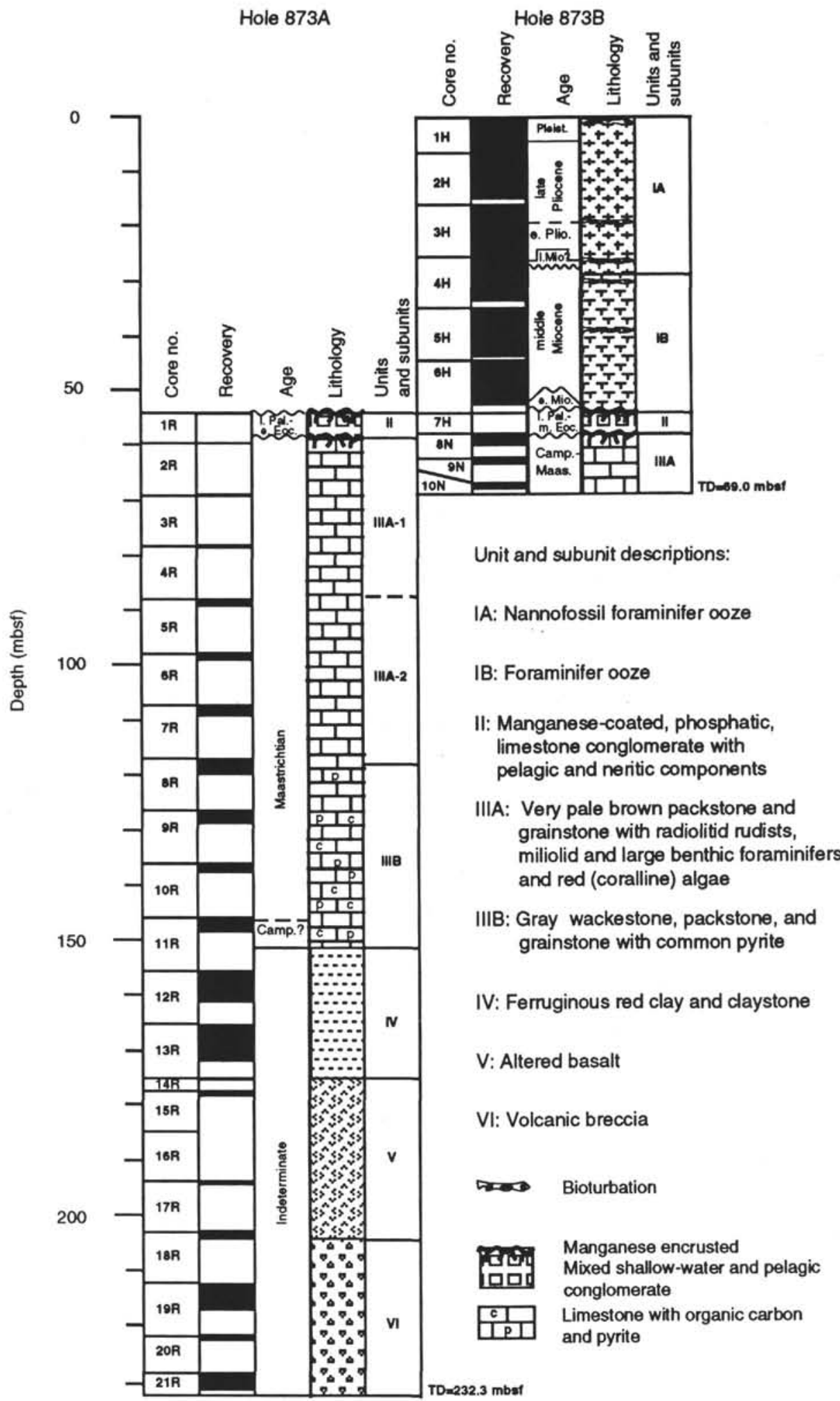

Figure 2. Lithostratrigraphic summary based on shipboard studies (Shipboard Scientific Party, 1993). Subunit IIIA has been divided into two sections based on the work reported in this paper. $\mathrm{TD}=$ total depth. 
corallinaceans and dasycladaceans), common molluscan molds (bivalve and gastropod), common to abundant radiolitid rudist (mostly fragmented), and rare caprinid rudist fragments. Two subunits were recognized in Unit III on the basis of color: Subunit IIIA is white to very pale brown whereas Subunit IIIB is pale brown to gray. The gray color results from up to $2 \%$ or $3 \%$ pyrite and organic carbon (Buchardt et al., this volume). Unit IV consists of $19.2 \mathrm{~m}$ of ferruginous clay and claystone, Unit $\mathrm{V}$ consists of altered alkalic basalt, and Unit VI consists of poorly sorted volcanic breccia.

\section{THIN-SECTION DATA FROM THE CARBONATE PLATFORM}

\section{Methods}

The cores from Site 873 containing platform carbonates were examined and visually described aboard the JOIDES Resolution. Detailed logs of color, carbonate and noncarbonate content, fossil and particle constituents, lithification, sedimentary structures, porosity, and cement abundance and type were compiled. Samples for shipboard and shore-based thin-section analysis were selected as representative of the different sedimentary facies and of variations within the same facies. Visual estimates of fossil type and abundance, particle type and abundance, cement type and abundance, and porosity type and abundance were compiled along with lithologic and sedimentary structure descriptions for a total of 83 shipboard thin sections and 92 shore-based thin sections. Rock names are based on Embry and Klovan's (1971) amplification of the original Dunham (1962) classification. Porosity descriptions follow the classification of Choquette and Pray (1970) and cement terminology and notations follow Folk (1965).

\section{Results}

Fossil, matrix, nonskeletal component, noncarbonate component, cement, and porosity abundances are plotted vs. depth in Figure 3. Fossil abundance throughout Subunit IIIB and the lower part of Subunit IIIA ranges from $30 \%$ to $70 \%$ in Core $144-873$ A-11R, gradually changing to a range of $0 \%-80 \%$ in Core $144-873 \mathrm{~A}-7 \mathrm{R}$, then to $5 \%-60 \%$ in Core $144-873 \mathrm{~A}-5 \mathrm{R}$. The most obvious change in fossil abundance occurs between Cores $144-873 \mathrm{~A}-5 \mathrm{R}$ and $-4 \mathrm{R}$. There is a general increase in matrix abundance from Core $144-873 \mathrm{~A}-11 \mathrm{R}$ to Core 144-873A-5R. The general increase in matrix abundance corresponds with a slight decrease in fossil abundance over the same interval. Matrix abundance drops sharply between Cores 144-873A$4 \mathrm{R}$ and $-5 \mathrm{R}$. Trends in nonskeletal carbonate components, such as peloids, pellets, and clasts, mimic the matrix trends. The elevated noncarbonate percentages near the top of the hole are stem from the manganese oxide encrustation in Unit II. The increasing noncarbonate percentages from about 100 mbsf to the base of the carbonate section reflect the increasing amounts of pyrite and organic carbon characteristic of Subunit IIIB. The abundance of cement ranges from $0 \%$ to $70 \%$ in Cores $144-873 \mathrm{~A}-11 \mathrm{R},-10 \mathrm{R}$, and $-9 \mathrm{R}$ and drops to generally less than $20 \%$ for most samples from cores above 144-873A$5 R$. Not surprisingly, porosity decreases as cement abundance increases from the base of Unit III to its top. Except for color differences caused by pyrite and organic carbon, it is apparent that variability is lower between Subunits IIIA and IIIB than it is within Subunit IIIA.

Because of the variability present within it, Subunit IIIA has been divided between Cores 144-873A-5R and -4R for the purpose of calculating lithologic unit averages of thin-section constituents in Table 1. Subunit IIIA-1 includes all of Subunit IIIA from Hole 873B and the top of Subunit IIIA through and including Core 144-873A-4R (58-88 mbsf). Subunit IIIA-2 includes Core 144-873A-5R through Section 144-873A-8R-1, $76 \mathrm{~cm}$ ( $88-118 \mathrm{mbsf})$. Table 1 contains the lithologic unit averages for the components plotted in Figure 3 as well as lithologic unit abundances of specific fossil and nonskeletal components.

In general, the trends apparent in Figure 3 are also apparent in the lithologic unit averages. For example, average fossil abundance for
Unit III is indistinguishable from the averages for both Subunits IIIA and IIIB. However, when Subunit IIIA is divided, Subunit IIIA-2 shows a slight decline in fossil abundance compared with Subunit IIIB. However, the fossil abundance is much higher in Subunit IIIA-1 $(52 \%)$ than it is in either Subunit IIIA-2 $(32.5 \%)$ or Subunit IIIB $(39.8 \%)$. The abundance of matrix varies even more: the average matrix in Subunit IIIA-2 (40.3\%) is nearly double the matrix abundance in Subunit IIIB (23\%). Matrix abundance then drops to $11.8 \%$ in Subunit IIIA-1. Lithologic unit averages of cement and porosity also reflect the trends apparent in Figure 3. Cement abundance is highest in Subunit IIIB (19.3\%) and drops to $7.7 \%$ and $7.9 \%$ in Subunits IIIA-2 and IIIA-1, respectively. The lowest cement abundance is in Unit II (1.4\%). Porosity, on the other hand, increases from $4.8 \%$ in Subunit IIIB to $6.8 \%$ in Subunit IIIA-2 to $17 \%$ in Subunit IIIA-1. Porosity drops to a low of $2.3 \%$ in Unit I.

The trends in component, cement, and porosity abundance are generally consistent with the depositional textures identified in thin section (Table 2). Subunit IIIB is dominated by packstones throughout with frequent grainstone textures described in Cores 144-873A-10R and $-11 \mathrm{R}$ and at the top of Core 144-873A-9R. Only a few wackestones are scattered throughout Subunit IIIB. Most of the matrix-rich textures described for Subunit IIIB are transitional between wackestone and packstone. Subunit IIIA-2, on the other hand, is dominated by packstone, wackestone, and intermediate packstone/wackestone textures. Only a few grainstone textures are identified in the upper cores (top of Cores 144-873A-6R and -5R) of Subunit IIIA-2. The increase in matrix-rich textures in Subunit IIIA-2 relative to Subunit IIIB explains the higher average matrix abundance and concurrent drop in fossil abundance in the former subunit. Even though the abundance of finegrained matrix rises sharply from Subunit IIIB to Subunit IIIA-2, we do not observe a concomitant reduction in porosity; rather, porosity actually increases slightly from the coarser Subunit IIIB to the finer Subunit IIIA-2. These apparently contradictory trends are caused by the fact that much of the original porosity of Subunit IIIB is now filled by mostly equant calcite cement. Cement averages $19.3 \%$ in Subunit IIIB and only $8 \%$ in Subunit IIIA-2.

The depositional textures of Subunit IIIA-1 are similar to those in Subunit IIIB: the subunit is dominated by packstone and grainstone with only a few wackestone to packstone textures identified near the top (Core 144-873B-8N). Algal bindstone is present at the base of the subunit (Core 144-873A-4R). Porosity is higher in this subunit (17\%) and cement abundance is lower $(7.9 \%)$ than in Subunit IIIB, even though the depositional textures are comparable. However, the total cement plus porosity is nearly the same, about $25 \%$, for both Subunits IIIB and IIIA-1, implying that the original porosity of the packstone/ grainstone facies in these subunits was about the same. The total cement plus porosity in Subunit IIIA-2 is about $10 \%$ lower than in the other two subunits, indicating a lower original porosity for the matrixrich facies.

Planktonic foraminifers are only abundant as internal sediment in Unit II. Smaller benthic foraminifers (e.g., small discorbids) and miliolid foraminifers are most abundant in the muddier facies of Subunit IIIA-2 (average abundances of $1 \%$ and $3 \%$, respectively). Larger benthic foraminifers are most abundant in Subunit IIIA-1 as are echinoderm fragments, red algae, and rhodoliths (whole and fragmented). Occasional coral fragments only occur in Subunits IIIA-1 and IIIB. Gastropods, on the other hand, are most abundant (as molds) in Subunit IIIA-2. Pelecypod fragments (non-rudist) and radiolitid rudist fragments are ubiquitous throughout (about $9 \%$ and $5 \%$, respectively).

Micritic envelopes are found only in the grainier facies of Subunits IIIA-1 and IIIB. Pellets and peloids are most abundant in Subunit IIIA-2, whereas clasts are more common in Subunits IIIA and IIIB. Manganese oxide crusts and staining are abundant only in Unit II at the top of the carbonate platform. Pyrite and noncarbonate organic matter is most abundant in Subunit III and present in trace amounts in Subunit IIIA-2. These noncarbonate components are absent in Subunit IIIA-1. 
Table 1. Average abundance and $95 \%$ confidence interval for various components identified in Site 873 thin sections.

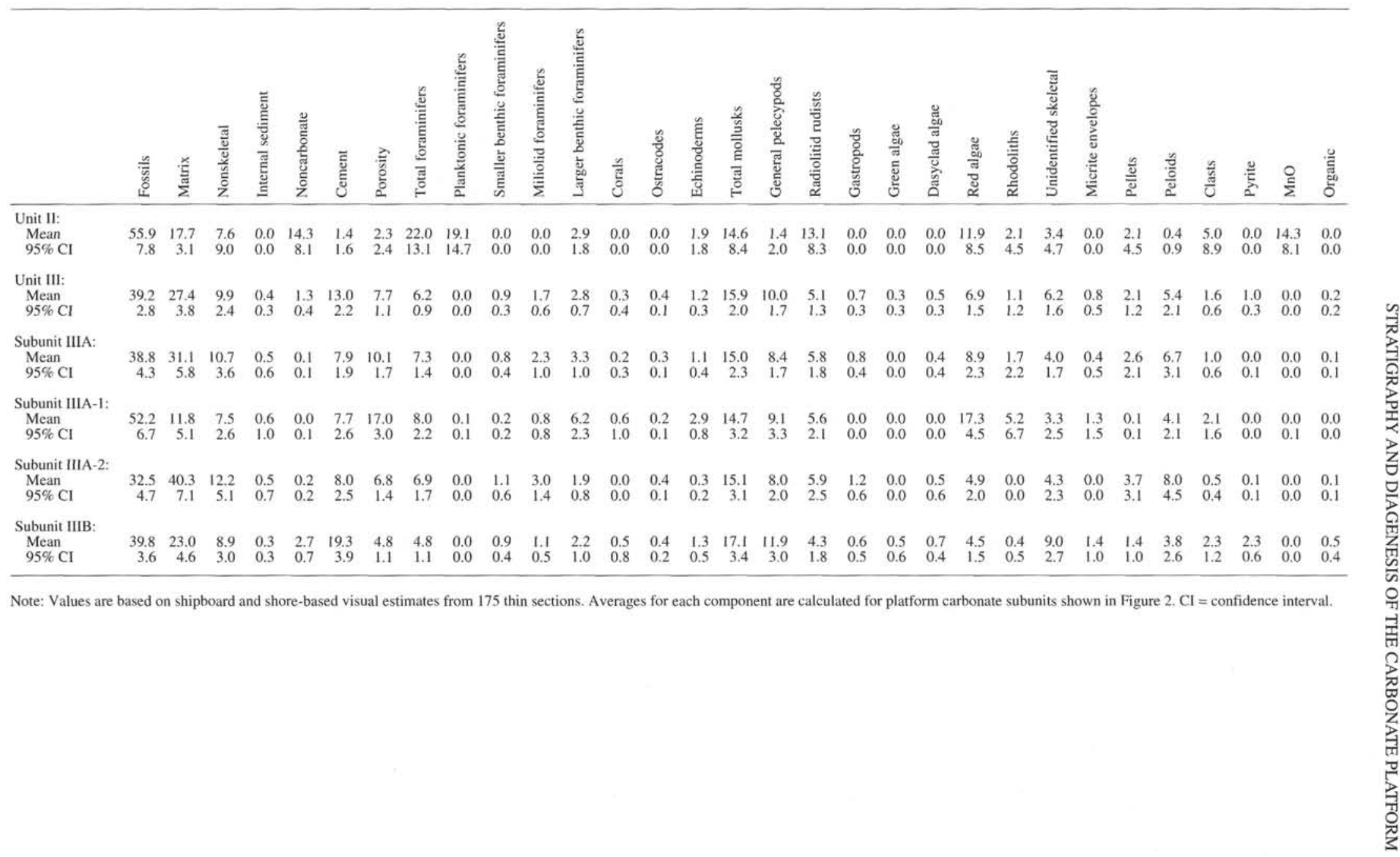


Table 2. Depositional textures for 175 thin sections from Site 873.

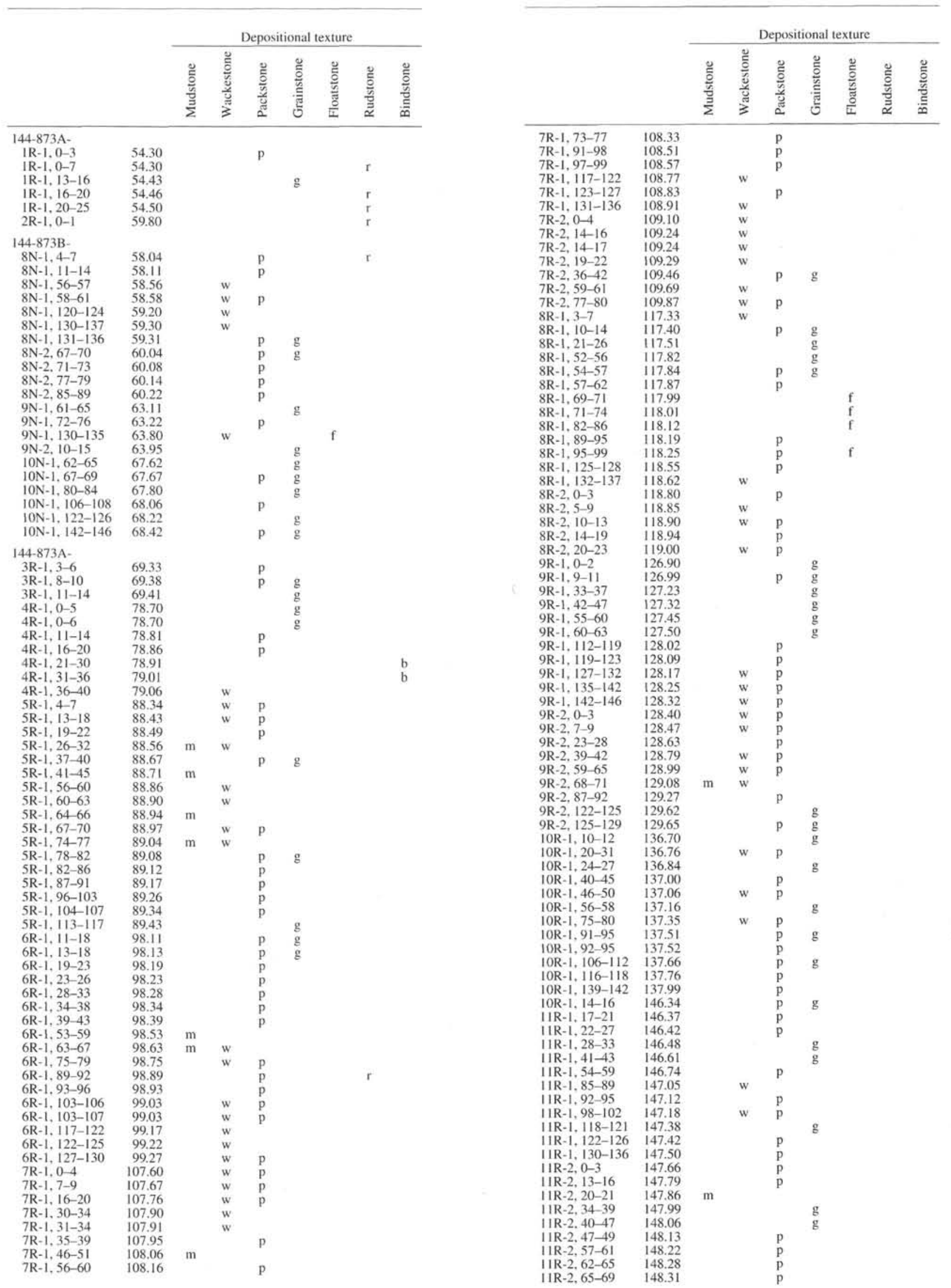


Table 2 (continued).

\begin{tabular}{|c|c|c|c|c|c|c|c|c|}
\hline & & \multicolumn{7}{|c|}{ Depositional texture } \\
\hline & & $\frac{\mathscr{g}}{\frac{g}{g}}$ & 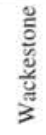 & $\begin{array}{l}\frac{g}{g} \\
\frac{g}{g} \\
\text { g. }\end{array}$ & 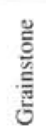 & 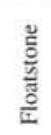 & 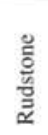 & 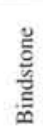 \\
\hline $11 \mathrm{R}-2,74-77$ & 148.40 & & & $\mathrm{p}$ & & & & \\
\hline $11 \mathrm{R}-2,85-90$ & 148.51 & & & $\mathrm{p}$ & $\mathrm{g}$ & & & \\
\hline IIR- $-2,90-98$ & 148.55 & & & $\mathrm{p}$ & & & & \\
\hline $11 \mathrm{R}-2,105-107$ & 148.71 & & & $\mathrm{p}$ & & & & \\
\hline $11 R-2,113-116$ & 148.79 & & & $\mathrm{p}$ & & & & \\
\hline IIR-2, $116-120$ & 148.82 & & & & g & & & \\
\hline IIR-2, $124-129$ & 148.89 & & & & $\mathrm{~g}$ & & & \\
\hline $11 \mathrm{R}-2,135-139$ & 149.01 & & & & $\mathrm{~g}$ & & & \\
\hline $11 R-2,140-145$ & 149.06 & & & $\mathrm{p}$ & $\mathrm{g}$ & & & \\
\hline IIR-2, $142-146$ & 149.07 & & & $\mathrm{p}$ & & & & \\
\hline $12 \mathrm{R}-1,0-5$ & 155.90 & & & & g & & & \\
\hline
\end{tabular}

Notes: Data have been arranged by depth (mbsf). Textural terms follow Embry and Klovan's (1971) modification of the Dunham (1962) classification.

Bioturbation is abundant throughout all of Unit III, although it is most apparent in the finer grained textures. Coarse/fine laminations, wavy laminae, planar fabric, and imbrication of grains is most common in the grainier packstones and grainstones. Geopetals are common throughout Unit III in molds, burrows, intraparticle pores, and shelter pores. Rhizoliths are present in Core 144-873A-5R near the top of Subunit IIIA-2 (Fig. 4). The other type of porosity in this core resembles fenestrae, but it may have been formed as roots pushed grains aside (Fig. 5). There is no obvious indication of dissolution associated with the large pores. These "fenestrae" are partly filled with apparent vadose silt. This evidence for subaerial exposure at the top of Subunit IIIA-2 is supported by stable carbon and oxygen isotope data (discussed in the following section).

\section{Interpretation}

The grainstones and packstones at the base of Subunit IIIB formed during the initial transgression of the subsiding volcanic edifice. The coarse-grained textures and sedimentary structures suggest a relatively high-energy platform open to marine influences. The organic carbon remains at the base of this subunit suggest high input of terrestrial vegetation (Buchardt et al., this volume); there was probably an emergent volcanic island nearby. The gray color and abundant pyrite suggest anoxic conditions, but the depositional textures and fossil assemblage (abundant red algae, rudist fragments, larger benthic foraminifers, echinoderm fragments) do not. The anoxia may be postdepositional: as the edges of the carbonate platform grew, Site 873 gradually became more and more restricted in the center of the platform. A combination of restricted circulation in the pore space of Subunit IIIB and the original high organic content resulted in postdepositional anoxia.

Toward the top of Subunit IIIB and into Subunit IIIA-2, the abundance of mud increases and the general diversity of the fossil assemblage decreases. We see a decline in echinoid debris and an increase in gastropod molds, miliolid foraminifers, pellets, and peloids. Echinoderm debris abundance drops as does lithoclast abundance. As the carbonate platform grew, and most likely widened through progradation (Camoin et al., this volume), the energy regime at Site 873 dropped and marine conditions become more restricted. Normal marine influences do not totally disappear at Site 873 . Even within the muddy intervals, there are still occasional grainy textures that are likely periodic storm deposits. Frequent layers interpreted as storm deposits are also apparent in the logging results (see later section in this paper). The decline in pyrite and/or organic carbon between Subunits IIIB and IIIA-2 may have resulted from the decline in organic matter flux as a central volcanic island sank below sea level.
The top of Subunit IIIA-2 ends with an apparent subaerial exposure inferred from the presence of rhizoliths and possible vadose silts.

The rhodolith facies and the abundance of loosely cemented grainstones present in Subunit IIIA-1 suggests a return to conditions similar to those that formed the base of Subunit IIIB: marine transgression of an exposure surface. This boundary is placed between Cores 144$873 \mathrm{~A}-5 \mathrm{R}$ and $-4 \mathrm{R}$, based on the lithofacies, and is placed at about the same position (near $90 \mathrm{mbsf}$ ), based on the logging interpretation (see later section in this paper).

The restricted lagoon environmental conditions do not reappear within Subunit IIIA. It is possible that carbonate production at the edges of the platform could not reestablish itself during the transgression that deposited this subunit.

\section{STABLE CARBON AND OXYGEN ISOTOPE DATA}

\section{Purpose}

The limestones that cap a volcanic edifice in an intraplate oceanic setting may be exposed to a wide range of environments including shallow-marine, deep-marine, mixed-water phreatic, meteoric phreatic, meteoric vadose, and subaerial. As the limestones move among environments in response to local tectonic uplift, subsidence, and eustatic changes, they may acquire a distinctive diagenetic imprint from each environment. Various authors have shown that the depositional and diagenetic history of a limestone may be tracked using the carbon and oxygen isotope compositions of depositional components and late-stage cements (e.g., Hudson, 1977). Land (1970, 1973) and Land and Epstein (1970) have shown that subaerial exposure of limestones in Bermuda and Jamaica resulted in the dissolution of unstable, high-magnesium, marine carbonates in undersaturated, meteoric, phreatic waters, followed by the lining of cavities by more stable, low-magnesium calcite and dolomite. They found that the carbon isotope composition of the meteoric cements tend to be lighter than in marine carbonates because of the contribution of isotopically light soil-gas $\mathrm{CO}_{2}$ in the diagenetic meteoric waters.

Carbon and oxygen isotopes have been used by Gross and Tracey (1966) and Saller (1986) to confirm the subaerial origin of solution unconformities identified by Schlanger (1963) beneath Anewetak Atoll. Major and Matthews (1983) also identified isotopic evidence for meteoric diagenesis of some limestones recovered from beneath Midway Atoll. Saller (1986) has also used the carbon and oxygen isotope composition of sparry calcite cements from Anewetak subsurface limestones to argue that some limestone alteration at this site is deep marine rather that meteoric in origin. The purpose of isotopic sampling in the study of Site 873 limestones was to confirm the petrographic evidence presented by subaerial exposure, such as rhizoliths and possible vadose silts filling large pores (Figs. 4 and 5, respectively).

\section{Methods}

Larger benthic foraminifers, red algae, and rudist shell fragments were sampled from all depths, when present, to try to establish the original shallow-marine isotopic compositions. The degree of alteration of the biogenic components is variable; therefore, they may not provide the best baseline. The fine-grained matrix present in the abundant wackestones and packstones was sampled at all depths. The coarsely crystalline, low-magnesium, calcite cement that fills and lines much of the porosity in Site 873 limestones was also sampled. Blocky, pore-filling, low-magnesium calcites can be the product of meteoric diagenesis (Longman, 1980). On the other hand, Saller (1986) recently interpreted deep-marine conditions from the isotope compositions for some low-magnesium calcites from limestones recovered beneath Anewetak Atoll.

Small samples $(0.2-0.5 \mathrm{mg})$ of powdered carbonate were removed from polished slabs using a microscope-mounted drill assembly with drill bits of 20 and $500 \mathrm{~mm}$ diameter. The powdered samples were reacted at $73^{\circ} \mathrm{C}$ with three drops of anhydrous phosphoric acid in 

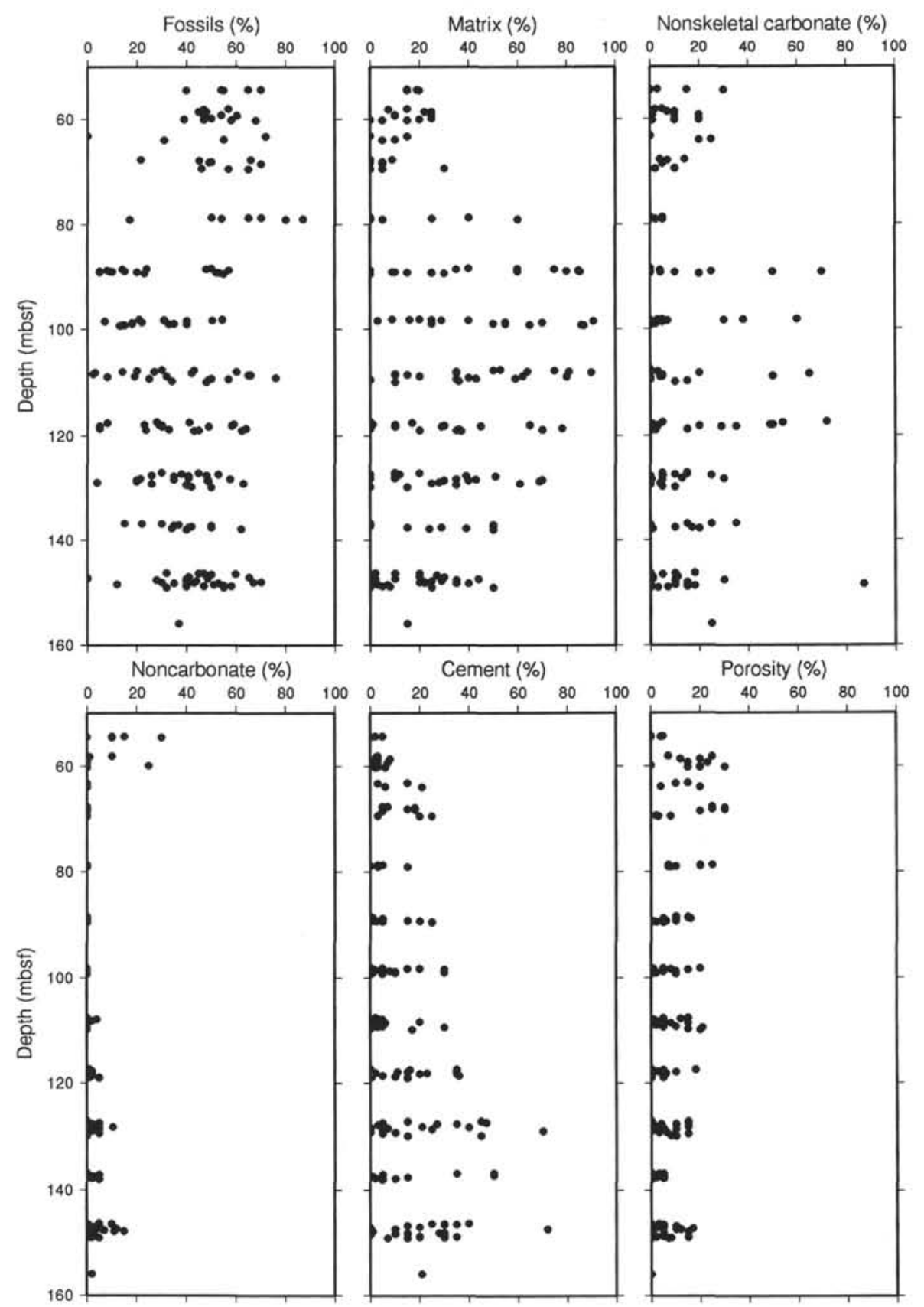

Figure 3. Total fossil, total matrix, total nonskeletal carbonate, total noncarbonate, cement, and porosity abundance are plotted vs. depth for 175 shipboard and shore-based thin-section analyses. The values plotted are based on visual estimates of components. Data for individual samples are available from ODP.

individual reaction vessels of an on-line, automated carbonate reaction device (Kiel Device) coupled to a Finnigan-MAT 251 mass spectrometer at the University of Michigan Stable Isotope Lab. Isotopic ratios were corrected for ${ }^{17} \mathrm{O}$ contribution and are reported in per mil $(\%)$ relative to the PDB standard. Precision was monitored through daily analyses of the NBS-20 calcite standard and is better than $0.1 \%$ ( $1 \mathrm{~s})$ for both $\mathrm{C}$ and $\mathrm{O}$ isotope compositions.

\section{Results and Interpretation}

The isotopic compositions of limestone components from Site 873 are listed in Table 3 and plotted in Figure 6. In general, the majority of fossil components have oxygen isotopic compositions between $-5 \%$ and $0 \%$ and carbon isotopic compositions between $3 \%$ and $0 \%$
(Fig. 6). The majority of matrix samples fall in the same range as the fossil components. These isotopic compositions are consistent with studies of reef and lagoonal sediments from modern atolls in the Marshall Islands (Gross and Tracey, 1966; Gonzalez and Lohman, 1985; Weber and Schmalz, 1968). The cement samples, in general, have carbon isotopic compositions ranging from $2 \%$ to $3 \%$ and oxygen isotopic compositions from $1 \%$ to $-1 \%$. These are typical values for marine cements forming at temperatures of $12^{\circ}-20^{\circ} \mathrm{C}$ and assuming seawater composition close to present values.

Five fossil samples, three matrix samples, and two cements have carbon and oxygen isotopic compositions more typical of meteoric diagenesis (i.e., negative carbon and oxygen values; Gross and Tracey, 1966; Land, 1970; Land and Epstein, 1970; Major and Matthews, 1983). Except for one matrix sample from interval 144-873A-9R-2, 


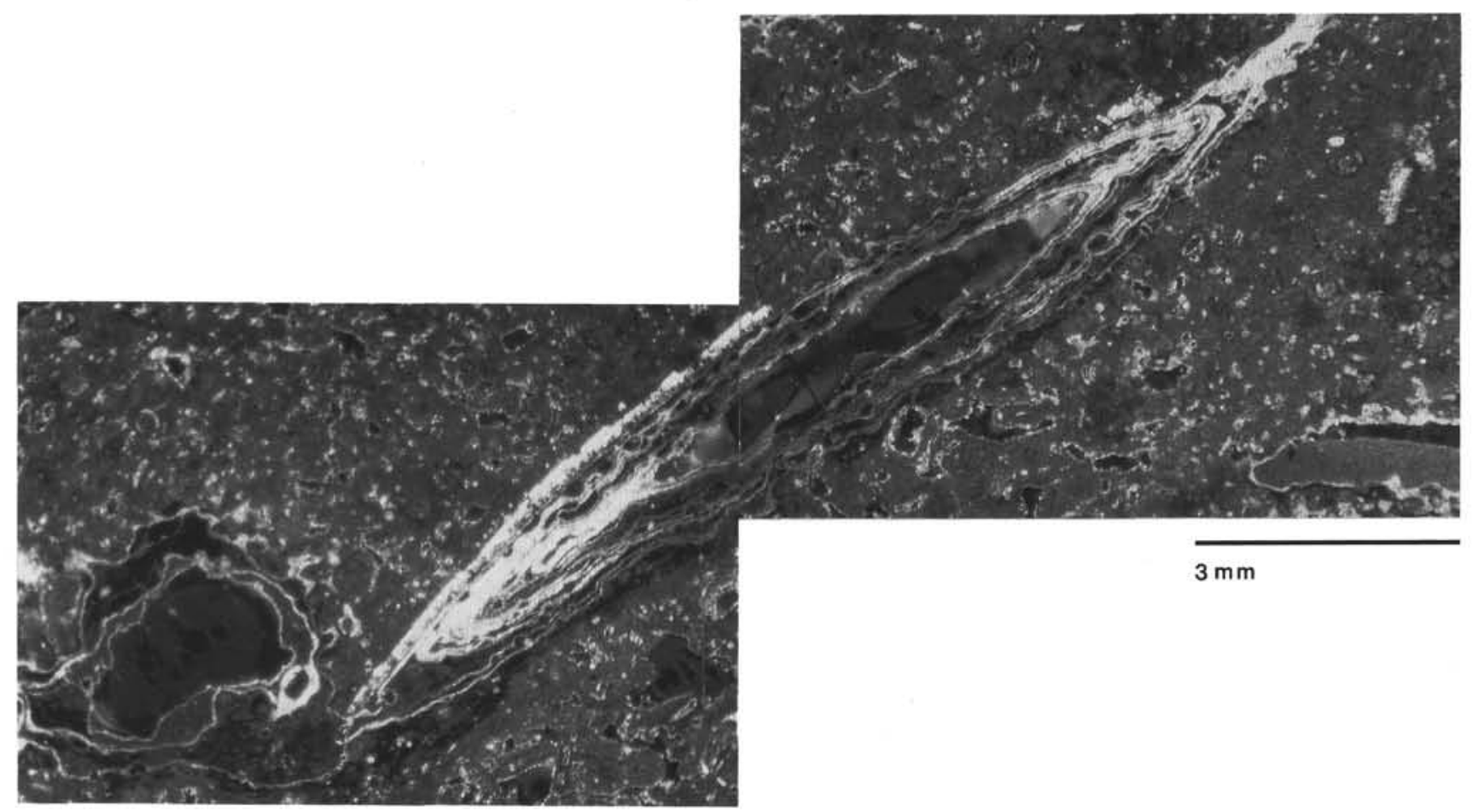

Figure 4. Photomicrograph (cross-polarized light) of a probable rhizolith in Sample 144-873A-5R-1, 37-40 cm. The bright band on top of the rhizolith is a thin mollusk shell. The shell may have formed a shelter pore or "seam" into which the root grew.

$23-28 \mathrm{~cm}$, that has a carbon isotopic composition of $-0.11 \%$, all of the samples with negative carbon isotopic values come from the very top of Subunit IIIA-2 and from throughout Subunit IIIA-1. The finegrained matrix from a sample with rhizoliths and possible vadose silt (Sample 144-873A-5R-1, 26-23 cm) has a carbon isotopic composition of $-0.83 \%$. This composition supports petrographic evidence for subaerial exposure at the top of Subunit IIIA-2.

Results from Subunit IIIA-1 are mixed. In Sample 144-873B$10 \mathrm{~N}-1,67-69 \mathrm{~cm}$, abundant micritic grain coatings have a positive carbon $(1.46 \%)$ and a negative oxygen $(-3.06 \%)$ isotopic composition, characteristic of the normal shallow-marine environment. However, an orbitoid foraminifer and red algae from this sample have negative carbon $(-1.38 \%$ and $-0.38 \%$, respectively) and very negative oxygen $(-5.39 \%$ and $-4.04 \%$, respectively) isotopic compositions. Although meniscus cements surrounding these components have a positive carbon composition $(0.78 \%$ ) , they do not plot with other cements from Site 873. This is one of only a few cements with carbon values less than $1 \%$ and oxygen composition less than $-2 \%$. In Sample 144-873B-9N-2, $10-15 \mathrm{~cm}$, a rudist fragment $\left(\delta^{13} \mathrm{C}=-2.22 \%\right.$, $\left.\delta^{18} \mathrm{O}=-4.67 \%\right)$, a red algal grain $\left(\delta^{13} \mathrm{C}=-4.28 \%\right.$, $\left.\delta^{18} \mathrm{O}=-4.81 \%\right)$, and coarse, isopachous, pore-filling cements $\left(\delta^{13} \mathrm{C}=-2.37 \%, \delta^{18} \mathrm{O}=\right.$ $-4.53 \%$ ) all have negative carbon compositions. In Sample 144$873 \mathrm{~B}-9 \mathrm{~N}-1,61-65 \mathrm{~cm}$, two specimens of the larger foraminifer $\mathrm{Om}$ phalocyclus were sampled. The first has an isotopic composition similar to modern lagoonal sediments in the Marshall Islands $\left(\delta^{13} \mathrm{C}=\right.$ $1.26 \%, \delta^{18} \mathrm{O}=-4.45 \%$ ), and the second has an isotopic composition more typical of meteoric diagenesis $\left(\delta^{13} \mathrm{C}=-1.71 \%\right.$, $\left.\delta^{18} \mathrm{O}=-5.17 \%\right)$. The chambers in the first foraminifer are empty, but the chambers in the second are filled with a clear, equant cement. The matrix surrounding the foraminifer also has a negative carbon composition $\left(\delta^{13} \mathrm{C}=-1.78, \delta^{18} \mathrm{O}=-5.26\right)$. The cement-filled foraminifer and wellcemented matrix correspond to irregular dense patches in this core first identified by the Shipboard Scientific Party (1993). The poorly cemented portions of this core have an isotopic composition closer to normal shallow marine $\left(\delta^{13} \mathrm{C}=1.29, \delta^{18} \mathrm{O}=-2.24\right)$.

The light carbon and oxygen isotopic compositions of Subunit IIIA-1 components may suggest either that parts of the subunit are supratidal, coarse sand deposits and that the meteoric alteration took place before burial or that the entire subunit was exposed to meteoric conditions, following original burial, during a eustatic lowstand. Lacking clear evidence of karst features that would be expected if the latter mechanism is correct, we propose that the former hypothesis is the most plausible explanation.

One cement sample in Subunit II (Sample 144-873B-8N-1, 4-7 $\mathrm{cm})$ has a slightly negative carbon isotopic composition $(-0.14 \%)$ and a very negative $(-7.8 \%$ ) oxygen isotopic composition. This cement is within a limestone clast that has been coated by manganese oxide. Only one cement from Site 873 (Sample 144-873A-1R-1, 0-3 cm) has an isotopic composition typical of cold marine waters. This is a single clear blade of calcite sitting in a manganese oxide-encrusted mollusk mold that was partly filled with early Tertiary planktonic foraminifers. The isotopic compositions of cements in limestones dredged from the sides of guyots in the Marshall Islands are generally typical of cold marine waters (positive carbon and positive oxygen; Lincoln, 1988). The lack of cold-marine cements from any part of Site 873 except the uppermost limestone may suggest restricted porewater circulation at this central platform site.

Another notable trend is the apparent increase in oxygen isotope compositions of both fossil components, matrix, and cements from the base of Subunit IIIB to the top of Subunit IIIA-2. The shift may be too large to be explained by changes in seawater composition as most of the platform was deposited during Maastrichtian time (Premoli Silva et al., this volume). This trend could be the result of a general deepening, and therefore general cooling, of the seawater at the site from the base of Subunit IIIB to the top of Subunit IIIA-2. If the cements are products of early diagenesis, then they should have acquired heavier oxygen isotopic compositions as the waters deepened. A slight shift to lower carbon compositions (one negative) in some of the matrix and cement in Core 144-873A-9R coupled with some very negative oxygen compositions for cement (e.g., Sample 144-873A-9R-2, 87-89 $\mathrm{cm}$ ) could indicate that the general deepening trend throughout Subunit IIIB was interrupted by a possible subaerial exposure in Core 144-873A-9R. Because of the poor core recovery, we do not have high enough resolution to pick up small-scale facies changes. 

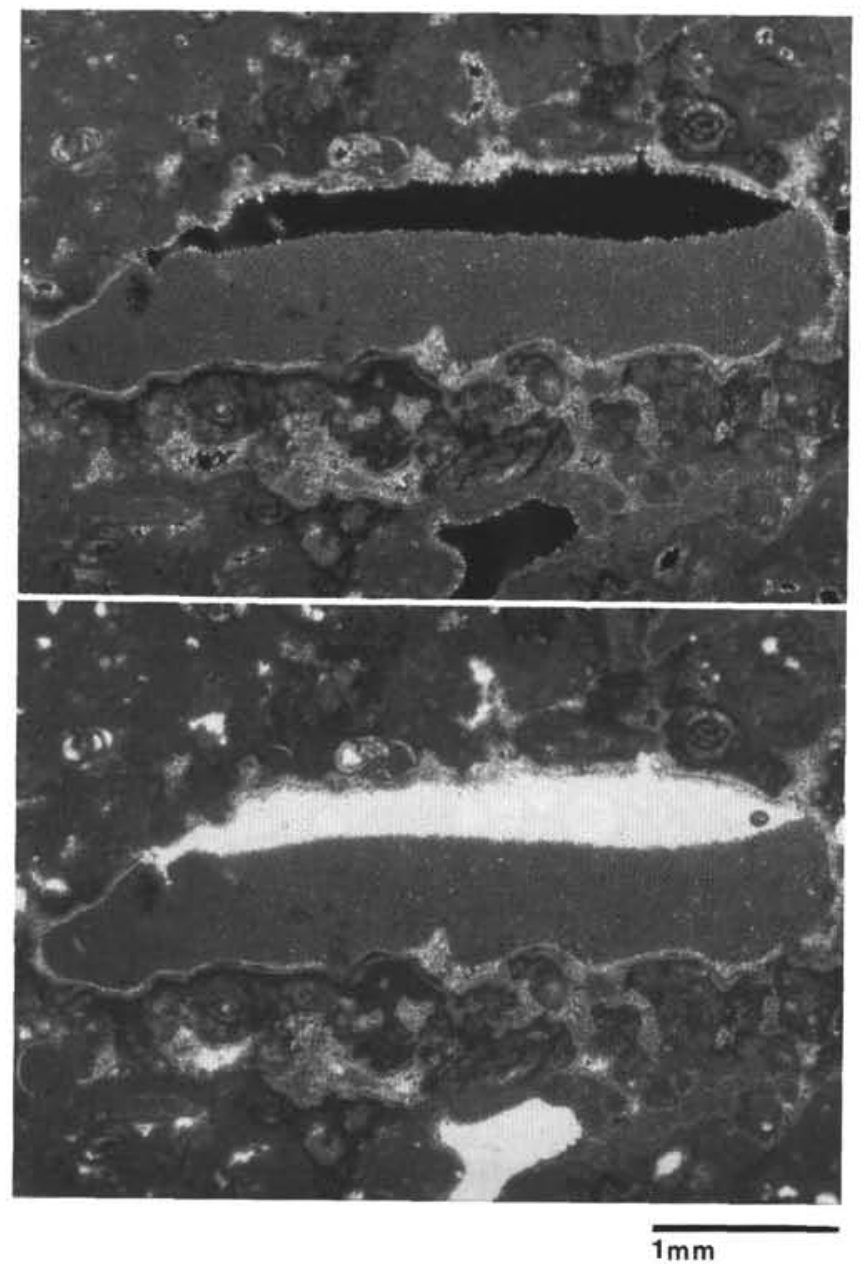

Figure 5. Photomicrograph (cross-polarized light on top, plane light on bottom) of "fenestra" in Sample 144-873-5R-1, 37-40 cm. The large pores do not cut grains, and there is no evidence of dissolution. A root may have pushed grains aside (see rhizolith in Fig. 4). The silt filling the large pore may be a vadose silt that sits on cement lining the pore.

\section{FACIES INTERPRETATIONS FROM DOWNHOLE LOGS}

\section{Introduction and Procedure for Facies Analysis}

In Hole 873A, suites of geophysical, geochemical, and Formation MicroScanner (FMS) downhole logs were obtained from about 223 (volcanic breccias underlying basalt flows) to $51 \mathrm{mbsf}$ (base of drill pipe). These logs are valuable for interpreting the sedimentary succession and possible discontinuities in accumulation within the carbonate platform. Core recovery within the platform carbonates was less than $20 \%$ in Hole $873 \mathrm{~A}$. In particular, the high-resolution, microresistivity, borehole-wall imagery from the FMS tool is excellent for determining the thickness and vertical succession of lithologies displaying similar "resistivity textures," which, in turn, can be interpreted as specific carbonate facies.

The procedure for interpreting the depositional history of Site 873 from the combination of core recovery and downhole logs consists of the following steps:

1. Depths of logging runs are calibrated to each other and related to coring depths. The FMS logs are graphically displayed in various formats and scales for visual interpretation of resistivity features. The geochemical logs are processed to obtain realistic relative fluctuations of each element.
Table 3. Carbon and oxygen isotope data for limestone components from Site 873.

\begin{tabular}{|c|c|c|c|c|}
\hline $\begin{array}{l}\text { Core, section, } \\
\text { interval }(\mathrm{cm})\end{array}$ & $\begin{array}{l}\text { Depth } \\
\text { (mbsf) }\end{array}$ & $\delta^{13} \mathrm{C}$ & $\delta^{18} \mathrm{O}$ & Component \\
\hline \multicolumn{5}{|l|}{$144-873 \mathrm{~A}-$} \\
\hline IR-1,0-3 & 54.30 & 0.90 & -4.16 & Rudist \\
\hline IR-1, 0-3 & 54.30 & 0.58 & -3.49 & Red algae \\
\hline IR-1, 0-3 & 54.30 & 2.16 & 2.87 & Cement \\
\hline \multicolumn{5}{|l|}{ 144-873B- } \\
\hline $8 \mathrm{~N}-1,4-7$ & 58.04 & 0.76 & -4.97 & Rudist \\
\hline $8 \mathrm{~N}-1,4-7$ & 58.04 & 0.80 & -3.63 & Red algae \\
\hline $8 \mathrm{~N}-1,4-7$ & 58.04 & -0.14 & -7.80 & Cement \\
\hline $8 \mathrm{~N}-2,67-70$ & 60.04 & 1.26 & -4.45 & Omphalocyclus \\
\hline $9 \mathrm{~N}-1,61-65$ & 63.11 & -1.71 & -5.17 & Omphalocyclus \\
\hline $9 \mathrm{~N}-\mathrm{I}, 61-65$ & 63.11 & -1.78 & -5.26 & Matrix \\
\hline $9 \mathrm{~N}-1,61-65$ & 63.11 & 1.29 & -2.24 & Matrix \\
\hline $9 \mathrm{~N}-2,10-15$ & 63.95 & -2.22 & -4.67 & Rudist \\
\hline $9 \mathrm{~N}-2,10-15$ & 63.95 & -4.28 & -4.81 & Red algae \\
\hline $9 \mathrm{~N}-2,10-15$ & 63.95 & -2.37 & -4.54 & Cement \\
\hline $10 \mathrm{~N}-1,67-69$ & 67.67 & -1.38 & -5.39 & Orbitoid \\
\hline $10 \mathrm{~N}-1,67-69$ & 67.67 & -0.38 & -4.04 & Red algae \\
\hline $10 \mathrm{~N}-1,67-69$ & 67.67 & 1.46 & -3.06 & Micrite env. \\
\hline $10 \mathrm{~N}-1,67-69$ & 67.67 & 0.78 & -6.00 & Cement \\
\hline $10 \mathrm{~N}-1,142-146$ & 68.42 & 1.85 & -3.24 & Rudist \\
\hline \multicolumn{5}{|l|}{$144-873 \mathrm{~A}-$} \\
\hline $4 \mathrm{R}-1,0-3$ & 78.70 & $\begin{array}{l}1.75 \\
0.63\end{array}$ & -2.14 & $\begin{array}{l}\text { Rudist } \\
\text { Red algae }\end{array}$ \\
\hline $4 \mathrm{R}-1,0-3$ & 78.70 & $\begin{array}{l}0.63 \\
2.30\end{array}$ & -0.91 & $\begin{array}{l}\text { Red algae } \\
\text { Cement }\end{array}$ \\
\hline $4 \mathrm{R}-1,0-3$ & 78.70 & & 0.48 & $\begin{array}{l}\text { Cement } \\
\text { Matrix }\end{array}$ \\
\hline $5 \mathrm{R}-1,26-32$ & 88.56 & $\begin{array}{r}-0.83 \\
1.14\end{array}$ & -0.62 & $\begin{array}{l}\text { Matrix } \\
\text { Matrix }\end{array}$ \\
\hline $5 R-1,60-63$ & 88.90 & 1.14 & -0.78 & \\
\hline 5R-1, 74-77 & 89.04 & 1.48 & 0.18 & Cement \\
\hline $5 R-1,87-91$ & 89.17 & 1.73 & -2.56 & Rudist \\
\hline $5 R-1,87-91$ & 89.17 & 2.88 & -0.53 & Orbitoid \\
\hline $5 R-1,87-91$ & 89.17 & 2.35 & -0.04 & Cement \\
\hline $5 R-1,113-117$ & 89.43 & 2.96 & 0.66 & Cement \\
\hline $6 \mathrm{R}-1,28-33$ & 98.28 & 2.90 & -0.51 & Orbitoid \\
\hline $6 \mathrm{R}-1,63-67$ & 98.63 & 1.20 & -2.86 & Rudist \\
\hline $6 \mathrm{R}-1,63-67$ & 98.63 & 1.98 & -0.01 & Matrix \\
\hline $6 \mathrm{R}-1,63-67$ & 98.63 & 2.03 & 0.25 & Cement \\
\hline 6R-1, 89-92 & 98.89 & 0.39 & -2.85 & Rudist \\
\hline $6 R-1,89-92$ & 98.89 & 1.79 & 0.36 & Cement \\
\hline $6 \mathrm{R}-1,122-125$ & 99.22 & 1.90 & 0.38 & Cement \\
\hline $6 R-1,122-125$ & 99.22 & 2.15 & -0.20 & Matrix \\
\hline $7 \mathrm{R}-1,0-4$ & 107.60 & 2.11 & -0.16 & Matrix \\
\hline $7 \mathrm{R}-1,0-4$ & 107.60 & 3.03 & -0.26 & Cement \\
\hline $7 \mathrm{R}-1,46-51$ & 108.06 & 2.50 & -0.02 & Cement \\
\hline $7 R-1,46-51$ & 108.06 & 2.12 & -0.89 & Matrix \\
\hline $7 R-2,14-17$ & 109.24 & 2.34 & -1.20 & Rudist \\
\hline $7 R-2,14-17$ & 109.24 & 2.54 & 0.88 & Cement \\
\hline $7 R-2,14-17$ & 109.24 & 2.79 & -0.54 & Matrix \\
\hline $7 \mathrm{R}-2,14-17$ & 109.24 & 2.77 & -0.46 & Matrix \\
\hline $8 \mathrm{R}-1,132-137$ & 118.62 & 0.31 & -1.68 & Matrix \\
\hline $8 R-1,132-137$ & 118.62 & 1.74 & -0.19 & Cement \\
\hline $8 \mathrm{R}-1,98-95$ & 118.62 & 1.03 & -3.38 & Rudist \\
\hline $8 R-1,98-95$ & 118.62 & 2.51 & -0.29 & Cement \\
\hline $8 R-1,14-19$ & 118.62 & 2.70 & 0.19 & Cement \\
\hline $8 \mathrm{R}-1,14-19$ & 118.62 & 0.11 & -2.07 & Orbitoid \\
\hline $9 \mathrm{R}-1,9-11$ & 126.99 & 0.67 & -1.23 & Orbitoid \\
\hline $9 \mathrm{R}-1,9-11$ & 126.99 & 2.28 & -0.24 & Algae \\
\hline $9 \mathrm{R}-1,70-75$ & 127.60 & 2.17 & 0.45 & Cement \\
\hline $9 R-1,135-142$ & 128.25 & 2.08 & -1.39 & Cement \\
\hline $9 \mathrm{R}-2,23-28$ & 128.63 & -0.11 & -2.65 & Matrix \\
\hline 9R-2, 23-28 & 128.63 & 2.45 & -0.79 & Cement \\
\hline 9R-2, 87-92 & 129.27 & 0.92 & -3.77 & Rudist \\
\hline $9 \mathrm{R}-2.87-92$ & 129.27 & 0.84 & -4.16 & Cement \\
\hline $9 R-2,125-129$ & 129.65 & 1.92 & -0.98 & Red algae \\
\hline $9 \mathrm{R}-2,125-129$ & 129.65 & 2.06 & -0.67 & Cement \\
\hline I0R-1, $40-45$ & 137.00 & 0.92 & -2.23 & Rudist \\
\hline $10 \mathrm{R}-1.40-45$ & 137.00 & 1.58 & -2.49 & Cement \\
\hline $10 \mathrm{R}-1,40-45$ & 137.00 & 0.73 & -1.72 & Matrix \\
\hline IOR-1, $40-45$ & 137.00 & 2.51 & -0.20 & Matrix \\
\hline $10 \mathrm{R}-1,40-45$ & 137.00 & 1.99 & -0.60 & Cement \\
\hline $10 \mathrm{R}-1,91-95$ & 137.51 & 2.39 & -0.84 & Cement \\
\hline $11 \mathrm{R}-1,14-16$ & 146.34 & 2.58 & -1.02 & Cement \\
\hline $1 \mathrm{IR}-1,54-59$ & 146.74 & 2.51 & -0.21 & Cement \\
\hline IIR-1.98-102 & 147.18 & 0.41 & -4.27 & Rudist \\
\hline IIR-2, 34-39 & 147.99 & 1.50 & -2.34 & Matrix \\
\hline IIR-2, 57-61 & 148.22 & 1.40 & -3.03 & Rudist \\
\hline IIR-2, 90-98 & 148.55 & 2.84 & -0.62 & Cement \\
\hline $11 \mathrm{R}-2,124-129$ & 148.89 & 1.67 & -1.66 & Orbitoid \\
\hline IIR-2, 142-146 & 149.07 & 1.46 & -1.64 & Red algae \\
\hline $11 R-2,142-146$ & 149.07 & 1.94 & -0.79 & Red algae \\
\hline IIR-2, 142-146 & 149.07 & 0.89 & -2.17 & Red algae \\
\hline $11 \mathrm{R}-2,142-146$ & 149.07 & 1.46 & -0.45 & Cement \\
\hline $12 \mathrm{R}-1,0-5$ & 155.90 & 1.18 & -1.79 & Cement \\
\hline
\end{tabular}

Note: Isotope compositions are expressed as per mil (\%) relative to PDB calcite. 
Fossils
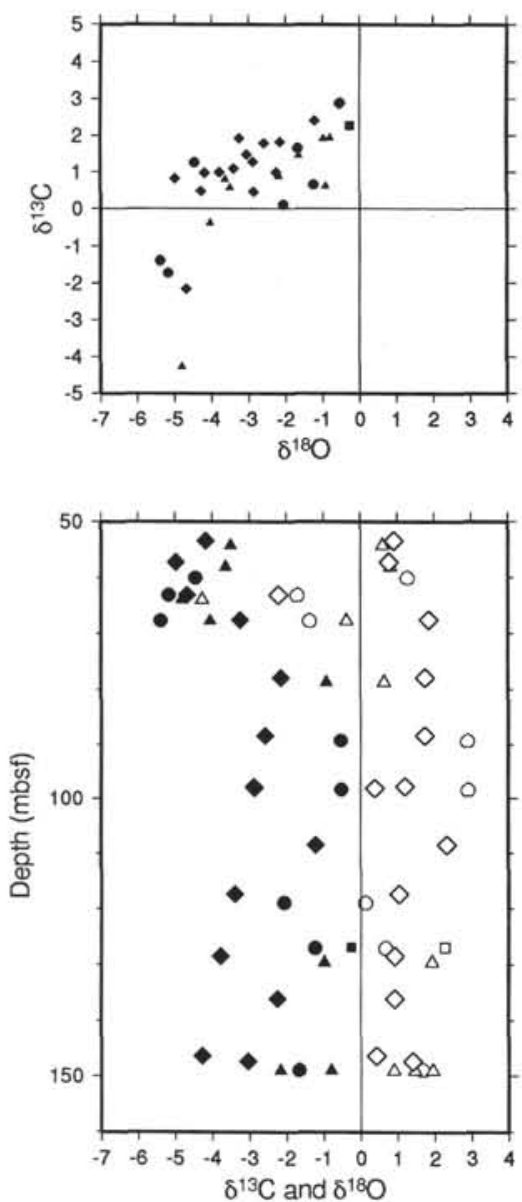

Matrix
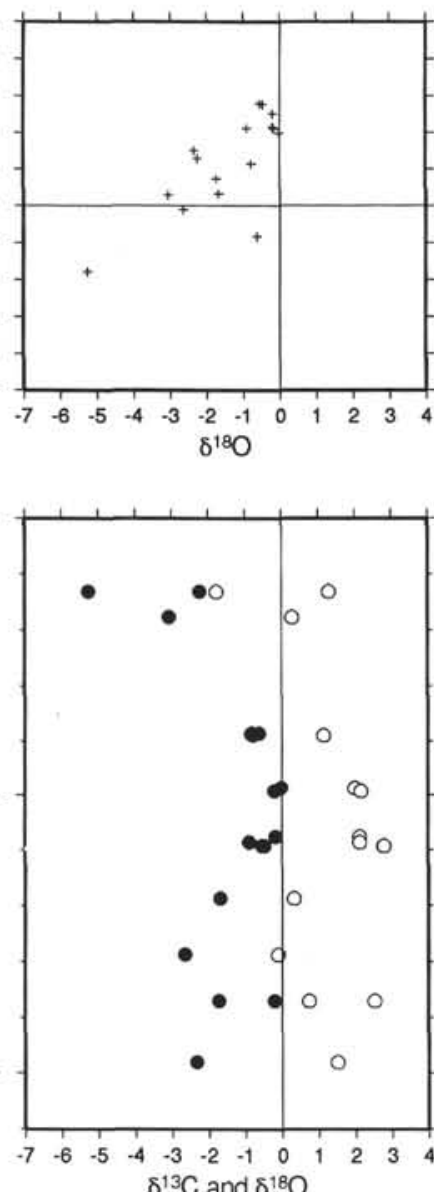

Cement
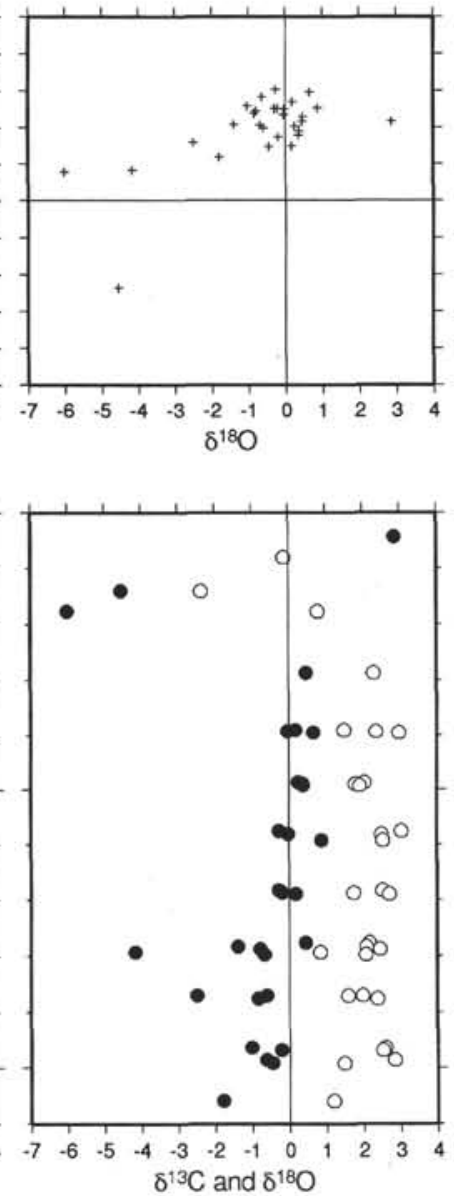

Figure 6. Stable carbon and oxygen isotope data are plotted for fossil components, matrix samples, and cements. For each component type, data are plotted first in a $\delta^{13} \mathrm{C}$ vs. $\delta^{18} \mathrm{O}$ scatter plot. These data are also plotted vs. depth for each material type. On the depth plots, the $\delta^{18} \mathrm{O}$ values are plotted as solid symbols and the $\delta^{13} \mathrm{C}$ values are plotted as open symbols. On the fossil component plots, circles show isotopic compositions for the larger benthic foraminifer, triangles show red algae values, diamonds show the rudist compositions, and squares show dasycladacean algae values.

2. Distinct carbonate facies recovered in cores are compared to the logging data to obtain a characteristic logging "signature" that will enable us to recognize these facies in intervals where core recovery was sparse. This "ground-truth" calibration was especially important for the FMS resistivity imagery.

3. A composite description of logging features and associated core recovery is made of the hole, which incorporates preliminary interpretation of the vertical succession of facies. The array of highresolution logging data enabled suites of lithologic subunits to be defined and facies succession trends to be distinguished.

4. The facies succession is interpreted in terms of shifting depositional environments and relative sea-level fluctuations.

At each level of this chain of interpretations, various assumptions and models need to be incorporated. A summary of the logging facies interpretations follows in the next section.

\section{Summary of Facies Interpretations Based on Logging}

\section{General Description of Unit III}

This unit is predominantly medium-resistivity lithology interbedded with distinct thin beds of medium-high to high resistivity (Fig. 7). The host sediment is foraminifer-algal-pellet wackestone-packstone, typical of a lagoonal setting.

\section{Log Characteristics of Storm Beds in Unit III}

The higher resistivity interbeds are generally about $10 \mathrm{~cm}$ thick (based on FMS data), have sharp bases and sharp or diffuse tops, and occur in quasi-random frequency (Fig. 8). These layers are interpreted to be storm beds of grainstone enriched in bivalves (rudist fragments) or foraminifers. The higher resistivity (lower porosity) of these storm beds relative to the host wackestone-packstone may indicate a preferential precipitation of cement within the more porous (initially) and lower organic-rich, storm-winnowed grainstones. Based on thin section observations, the subunits with grainier textures also have the lowest porosity and highest amount of cement (Table 1). Otherwise, one would expect the more mud-rich sediments to have the lower porosity (hence, a higher resistivity) in contrast to the observed facies.

Not all high-resistivity beds are planar storm beds; thin lenticular horizons were also noted in the FMS imagery. Some of these also may be the result of partial in situ winnowing of the host sediment by storm events. The maximum thickness observed for a high-resistivity bed is $0.5 \mathrm{~m}$. It is also possible that some of the high-resistivity layers are algal-bound layers; algal-packstone was recovered in interval 144873A-10R-1, 27-32 cm.

Thicker storm beds preferentially seem to occur within a lower resistivity host sediment, interpreted as a packstone. In contrast, there seems to be a greater frequency of thin storm events per stratigraphic 


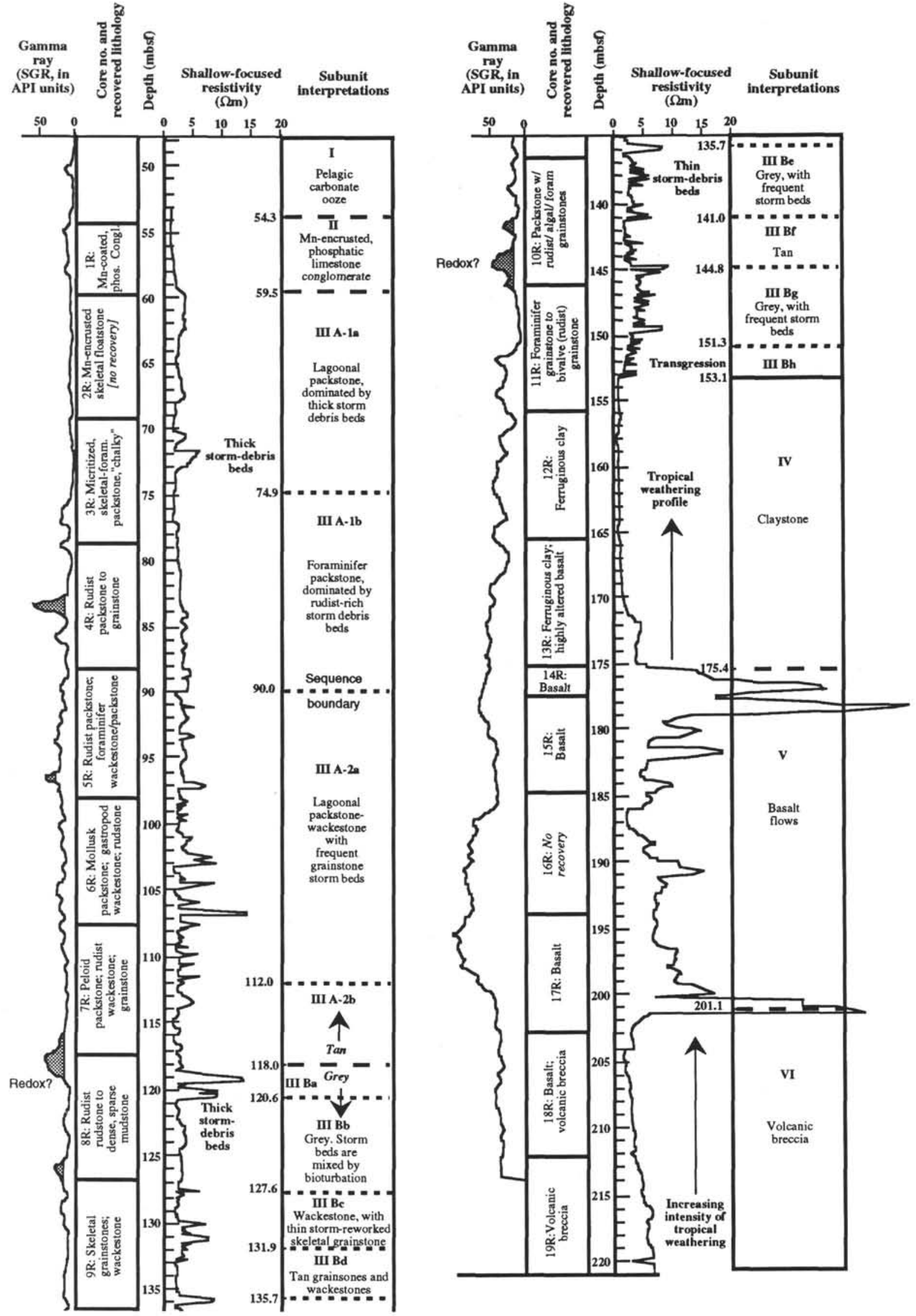

Figure 7. Plot of gamma-ray log, resistivity, and log facies identified using Formation MicroScanner data, Site 873. 
meter in the higher resistivity host sediment. The latter is interpreted to be a wackestone. This correlation may indicate (1) a relationship between storm-bed thickness and availability of coarse-grained material in the host sediment, and (2) a slower sedimentation rate (assuming storm-caused disruption of lagoonal sediments is a constant with time) for the wackestone-facies relative to the packstone-facies.

\section{Log Characteristics of Host Sediment in Unit III}

Changes in the average resistivity of the host sediment probably reflect changes in the abundances of carbonate mud. The stratigraphic plot of resistivity (Fig. 7) attempts to distinguish separate storm beds from the adjacent host sediments. Higher resistivities of the host sediment probably correspond to an increased proportion of wackestone, whereas lower resistivities correspond to a dominance by packstone. However, there is also a partial correlation between intervals with a greater abundance of high-resistivity storm beds, and it is possible that there are many thin storm-bed horizons that are "blurred" into the host sediment, resulting in an apparent higher "background" resistivity.

The unit has a moderate natural gamma-ray intensity, which is caused by the presence of uranium above the underlying clay. Clay, which could be detected by a thorium signal in the gamma-ray spectrum, apparently is scarce in the lower sediments of the carbonate platform deposited following the initial drowning of the weathered volcanic edifice. There is no apparent influx of terrigenous sediment onto the carbonate platform from the remaining emergent portions of the volcano. The gray Subunit IIIB is relatively enriched in uranium with respect to the overlying tan Subunit IIIA; this result is consistent with the postdepositional reducing (pyrite-precipitating) conditions in Subunit IIIB.

Anomalous concentrations in uranium, such as the peaks in natural gamma-ray intensity at $118.0,141.5$, and 144.8 mbsf, seem to correspond to changes between the gray and tan colors of the host wackestone-packstone. These uranium concentrations are probably at redox fronts between the relatively oxidized and reduced sediments.

\section{General Interpretation of Subunit IIIB}

The basal transgressive surface is obvious, but other interpretations of changes in relative sea-level or seaward-lagoonward shifts in depositional environments are not easily interpreted.

Within this succession are several alternating tan and grey layers. As discussed earlier, these grey horizons are thought to be the result of postdepositional anoxia caused by abundant organic matter in the lagoonal sediment. The cyclicity between such conditions is ca. $8 \mathrm{~m}$ based on core observations and the gamma-ray peaks. This cyclicity approaches the 6-m cyclicity of upward-shallowing sequences observed in Site 874 (Camoin et al., this volume). It is possible these color variations are the result of variations in organic matter flux from a nearby island.

Above the basal $9 \mathrm{~m}$, the frequency of storm beds (high-resistivity layers) decreases upward in Subunit IIIB. This trend is accompanied by an increase in bioturbation, evident by the "blurring" of highresistivity beds in the FMS data. These trends may be the result of a general deepening of the depositional environment from the base of Subunit IIIB to the top and may also be related to widening of the carbonate platform as the volcanic edifice subsides. During the initial transgression of the edifice, debris from storms of all sizes may have been able to breach the incipient carbonate platform and leave debris at Site 873. As the platform matured and widened, only the larger storms would be able to deposit debris in the deepening lagoon.

\section{General Description and Definition of Logging Facies in Subunit IIIA}

The log characteristics of the lower half of lithologic Subunit IIIA are very similar to the upper half of the underlying Subunit IIIB. Low-medium resistivity, homogeneous wackestone-packstones are

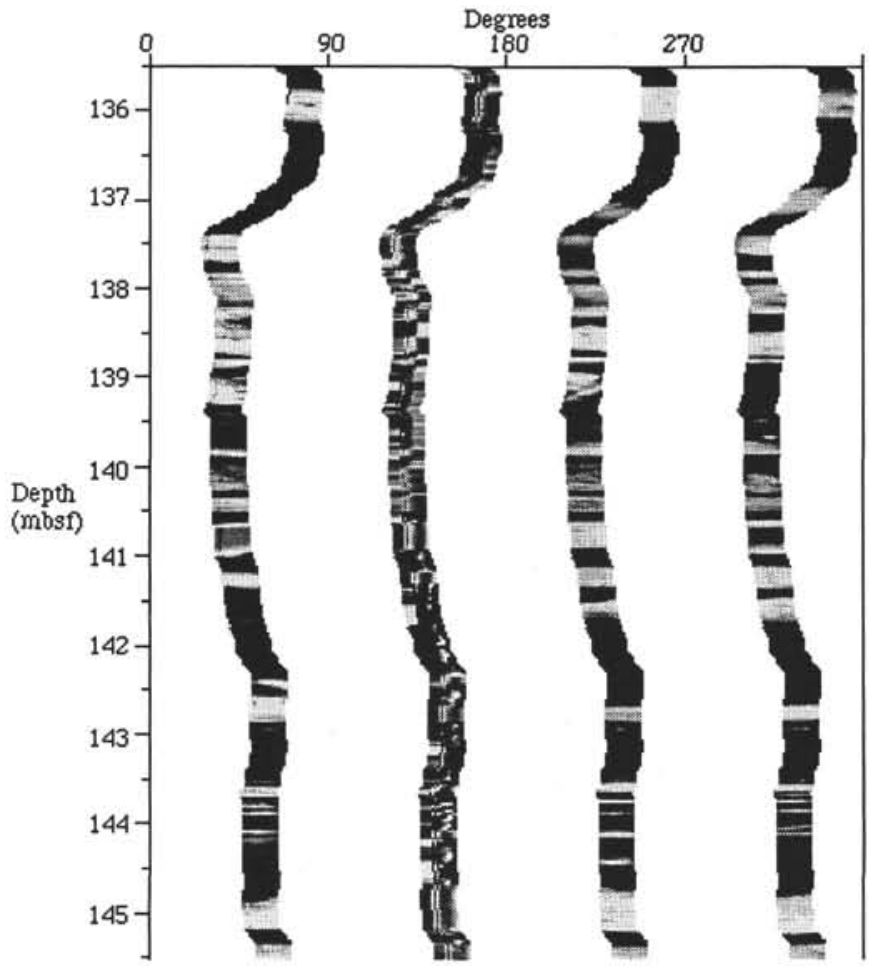

Figure 8. Formation MicroScanner images showing the thin bedding characteristic of the base of Subunit IIIB.

interbedded with high-resistivity grainstone storm beds. The upper half of Subunit IIIA has fewer, but thicker, higher resistivity layers, which may also be storm related (Fig. 9).

In general, the storm beds do not have well-defined upper surfaces, which may suggest partial bioturbation mixing. Bioturbation mixing may also explain the lack of thin storm beds, as are common within the gray facies of the underlying Subunit IIIB. Despite their higher resistivity, which suggests lower less porosity, the storm layers tend to preferentially wash out during drilling operations, resulting in an interesting inverse relationship between resistivity-density and borehole diameter. The resistivity-contrast between the host lagoonal sediment and the grainstone storm bed is not as pronounced in Subunit IIIA as it is in Subunit IIIB. Core recovery indicates that the coarser grained layers of Subunit IIIA are relatively enriched in rudist fragments relative to the storm-bed grainstones of the underlying Subunit IIIB.

The core recovery also suggests that the host lagoonal packstonewackestones of Subunit IIIA are generally less lime-mud-rich, relative to the underlying Subunit IIIB. Subunit IIIA was divided into logging-facies subunits according to the nature of the storm events:

Subunit IIIA-2b: infrequent and less distinct storm events;

Subunit IIIA-2a: more common and distinct storm beds, but top surfaces often "fuzzy";

Subunit IIIA-1b: common thick debris beds;

Subunit IIIA-1a: major storm-rubble (?) deposit at base.

\section{CONCLUSIONS}

Based on the study of shipboard and shore-based thin sections from the carbonate platform section of Site 873, we conclude that packstone and grainstone textures at the base of the platform (Core 144-873A-11R) generally shifted to dominantly packstone and wackestone textures in Cores 144-873A-7R, -6R, and $-5 R$. Beginning in Core 144-873A-4R and continuing to the top of the platform section, deposition decidedly shifted back to grainier textures. Based on the 


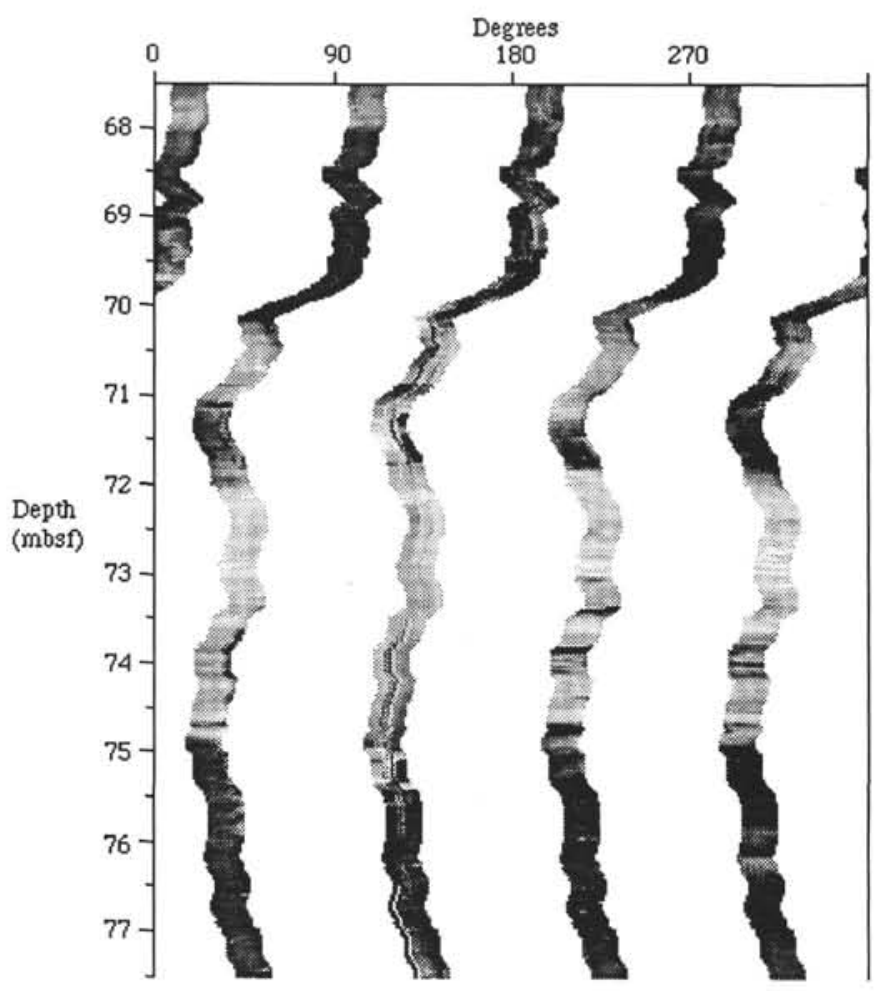

Figure 9. Formation MicroScanner images showing the thick bedding characteristic of Subunit IIIB.

textural variation in Subunit IIIA, we divided Subunit IIIA between Cores 144-873A-5R and -4R.

These textural trends are accompanied by related changes in cement, porosity, and fossil type and abundance. The grainstones were laid down during the initial transgression of the volcanic edifice, followed by a general deepening of the lagoon that resulted in an uphole increase in mud from the base of Subunit IIIB (the base of the carbonate platform) and the top of Subunit IIIA-2 (about $90 \mathrm{mbsf}$ ). Rhizoliths, possible fenestrae with vadose silt, and the negative carbon isotopic composition of the fine-grained sediment in parts of Core 144-873A$5 \mathrm{R}$ all suggest possible subaerial exposure. If this horizon is an exposure surface, then a second transgression event deposited grainstones and algal bindstone facies (Cores 144-873A-4R, $-3 \mathrm{R}$, and $-2 \mathrm{R}$; Cores $144-873 \mathrm{~B}-10 \mathrm{~N},-9 \mathrm{~N}$, and $-8 \mathrm{~N}$ ) on top of the exposure surface. The carbon and oxygen isotope composition of fossil components and cements in these cores suggests either occasional supratidal conditions and exposure to meteoric waters or a major episode of postdepositional subaerial exposure before the cessation of carbonate production on Wodejebato. The absence of significant karst features would seem to contraindicate the latter possibility.

Interpretation of facies based on physical and geochemical logs indicates that numerous grainy storm beds interrupt the deposition of more lagoonal wackestones and packstones throughout the carbonate platform section of Site 873 . The boundary between the wellcemented packstones and wackestones of Core 144-873A-5R and the overlying grainstones shows up at about 90 mbsf. A rapid shift to relatively shallower facies was identified at $90.0 \mathrm{mbsf}$ at the change between lagoonal sediments having distinct storm beds and the overlying facies with semicontinuous winnowed concentration of coarse bioclasts. In the interval with complete logs, it was not possible to identify unambiguously a final episode of deepening, as suggested by the facies recovered in Site 874 (Camoin et al., this volume).

The assignment of a transgressive surface at the top of Subunit IIIA-2 (about $90 \mathrm{mbsf}$ ) would project to a relative position of approximately 50 mbsf in Site 874, which is within the upper portion of the seaward parasequence-dominated progradation of the coral-algal bench, and which ignores the probability that the depositional setting on this inner perimeter ridge was shallower than that of the central portion of the lagoon. Considering (1) the difficulties of inferring "sequence boundaries" in a lagoonal or carbonate shelf environment and of assigning absolute depths to the facies, and (2) the probable depth difference between the lagoon and the semiemergent shoalcomplex sites, it is quite probable that the 90 -mbsf boundary assignment in Site 873 is identical to events that suggest a sequence boundary at about $41 \mathrm{mbsf}$ in Site 874 (Camoin et al., this volume).

\section{REFERENCES $*$}

Alldredge, L.R., Keller, F., and Dichtel, W.J., 1954. Magnetic structure of Bikini Atoll. Geol. Surv. Prof. Pap. U.S., 260-M:529-536.

Bergersen, D.D., 1993. Geology and geomorphology of Wodejebato (Sylvania) Guyot, Marshall Islands. In Pringle, M.S., Sager, W.W., Sliter, W.V., and Stein, S. (Eds.), The Mesozoic Pacific: Geology, Tectonics, and Volcanism. Geophys. Monogr., Am. Geophys. Union, 77:367-385.

Choquette, P.W., and Pray, L.C., 1970. Geologic nomenclature and classification of porosity in sedimentary carbonates. AAPG Bull., 54:207-250.

Cole, W.S., 1954. Larger foraminifera and smaller diagnostic foraminifera from Bikini drill holes. Geol. Surv. Prof. Pap. U.S., 260-O:569-608.

1957. Larger foraminifera from the Eniwetok Atoll drill holes. Geol. Surv. Prof. Pap. U.S., 260-V:743-784.

Dunham, R.J., 1962. Classification of carbonate rocks according to depositional texture. In Ham, W.E. (Ed.), Classification of Carbonate Rocks. AAPG Mem., 108-121.

Embry, A.F., and Klovan, J.E., 1971. A late Devonian reef tract on northeastern Banks Island, Northwest Territories. Bull. Can. Pet. Geol., 19:730-781.

Emery, K.O., Tracey, J.I., Jr., and Ladd, H.S., 1954. Geology of Bikini and Nearby Atolls. Geol. Surv. Prof. Pap. U.S., 260-A.

Folk, R.L., 1965. Some aspects of recrystallization in ancient limestones. In Pray, L.C., and Murray, R.C. (Eds.), Dolomitization and Limestone Diagenesis. Spec. Publ.-Soc. Econ. Paleontol. Mineral., 13:13-48.

Gonzalez, L.A., and Lohman, K.C., 1985. Carbon and oxygen isotopic composition of Holocene reefal carbonates. Geology, 13:811-814.

Gross, G.M., and Tracey, J.I., 1966. Oxygen and carbon isotope composition of limestones and dolomites, Bikini and Anewetak atolls. Science, 151:1082-1084.

Hamilton, E.L., and Rex, R.W., 1959. Lower Eocene phosphatized Globigerina ooze from Sylvania Guyot. Geol. Surv. Prof. Pap. U.S., 260-W:785797.

Hudson, J.D., 1977. Stable isotopes and limestone lithification. J. Geol. Soc. London, 133:637-660.

Land, L.S., 1970. Phreatic vs. vadose meteoric diagenesis of limestones: evidence from a fossil water table. Sedimentology, 14:175-185.

, 1973. Holocene meteoric dolomitization of Pleistocene limestone, North Jamaica. Sedimentology, 20:411-424.

Land, L.S., and Epstein, S., 1970. Late Pleistocene diagenesis and dolomitization, North Jamaica. Sedimentology, 14:187-200.

Lincoln, J.M., 1988. Isotopic record of marine diagenesis from Eocene reef limestones recovered from Harrie Guyot, Marshall Islands. Geol. Soc. Am. Abstr. Progr., 20:A260-A261.

Lincoln, J.M., Pringle, M.S., and Premoli-Silva, I., 1993. Early and Late Cretaceous volcanism and reef-building in the Marshall Islands. In Pringle, M.S., Sager, W.W., Sliter, W.V., and Stein, S. (Eds.), The Mesozoic Pacific: Geology, Tectonics, and Volcanism. Geophys. Monogr., Am. Geophys. Union, 77:279-305.

Longman, M.W., 1980. Carbonate diagenetic textures from nearsurface diagenetic environments. AAPG Bull., 64:461-487.

Major, R.P., and Matthews, R.K., 1983. Isotopic composition of bank margin carbonates on Midway Atoll: amplitude constraint on post-early Miocene eustasy. Geology, 11:335-338.

Petersen, L.D., Duennebier, F.K., and Shipley, T.H., 1986. Site surveys in the western Pacific conducted aboard the Kana Keoki, Cruise KK810626, Leg 4. In Moberly, S., Schlanger, S.O., et al., Init. Repts. DSDP, 89: Washington (U.S. Govt. Printing Office), 603-628.

\footnotetext{
- Abbreviations for names of organizations and publications in ODP reference lists follow the style given in Chemical Abstracts Service Source Index (published by American Chemical Society).
} 
Premoli Silva, I., 1986. A new biostratigraphic interpretation of the sedimentary record recovered at Site 462, Leg 61, Nauru Basin, western equatorial Pacific. In Larson, R.L., Schlanger, S.O., et al., Init. Repts. DSDP, 61: Washington (U.S. Govt. Printing Office), 311-319.

Premoli Silva, I., Haggerty, J., Rack, F., et al., 1993. Proc. ODP, Init. Repts., 144: College Station, TX (Ocean Drilling Program).

Raitt, R.W., 1954. Seismic refraction studies of Bikini and Kwajalain atolls and Sylvania Guyot. Geol. Surv. Prof. Pap. U.S., 260-K:507-528.

Saller, A.H., 1986. Radiaxial calcite in lower Miocene strata, subsurface Enewetak Atoll. J. Sediment. Petrol., 56:743-762.

Schlanger, S.O., 1963. Subsurface geology of Eniwetak Atoll. Geol. Surv. Prof. Pap. U.S., 260-BB:991-1066.
Shipboard Scientific Party, 1993. Site 873. In Premoli Silva, L., Haggerty, J., Rack, F., et al., Proc. ODP, Init. Repts., 144: College Station, TX (Ocean Drilling Program), 145-207.

Weber, J.N., and Schmalz, R.F., 1968. Factors affecting the carbon and oxygen isotopic composition of marine carbonate sediments. Part III: Eniwetok Atoll. J. Sediment. Petrol., 38:1270-1279.

Date of initial receipt: 26 January 1994

Date of acceptance: 15 September 1994

Ms 144SR-040 